\title{
Meningkatkan kemandirian dan hasil belajar siswa dengan aplikasi kas kecil (EPCA) berbasis website (A useful web- based learning media in the COVID-19 era)
}

\author{
Yashinta Ula Qomarina, Madziatul Churiyah *, Heri Pratikto \\ Universitas Negeri Malang, Jl. Semarang No. 5 Malang, Jawa Timur, Indonesia \\ *Penulis korespondensi, Surel: madziatul.churiyah.fe@um.ac.id
}

Paper received: 2-1-2021; revised: 23-1-2021; accepted: 30-1-2021

\begin{abstract}
Abstrak
Adanya pandemi Covid 19 membuat guru dan siswa dituntut untuk dapat beradaptasi dengan sistem pembelajaran baru, yakni pembelajaran jarak jauh. Selain itu guru juga dituntut untuk membuat media pembelajaran dengan memanfaatkan teknologi, sehingga dapat diakses siswa secara online. Penelitian dan pengembangan ini berupa media pembelajaran Otomatisasi Tata Kelola Keuangan yang bernama EPCA (Educative Petty Cash Application) Berbasis Website untuk meningkatkan kemandirian dan hasil belajar siswa. Di dalam EPCA terdapat menu simulasi kas kecil dimana siswa dapat melakukan praktikum pencatatan kas kecil secara digital di dalamnya. Selain itu juga terdapat menu soal latihan yang di dalamnya terdapat soal-soal pilihan ganda untuk mengasah kemampuan kognitif siswa. Penelitian dan pengembangan ini menggunakan model Research and Development Sugiyono yang telah dimodifikasi. Teknik analisis data yang digunakan adalah deskriptif presentasi dan uji independent sample t-test. Hasil penelitian ini dan pengembangan ini adalah media pembelajaran kas kecil berbasis website bernama EPCA (Educative Petty Cash Application) yang masuk dalam kategori sangat valid dan layak digunakan sebagai media pembelajaran otomatisasi tata kelola keuangan oleh ahli materi, ahli media, dan subjek uji coba kelompok kecil serta terbukti dapat meningkatkan kemandirian dan hasil belajar siswa secara signifikan pada uji coba kelompok besar. Berdasarkan hal tersebut dapat disimpulkan bahwa aplikasi EPCA sebagai media pembelajaran kas kecil layak dan efektif digunakan untuk meningkatkan kemandirian dan hasil belajar siswa pada mata pelajaran otomatisasi tata kelola keuangan.
\end{abstract}

Kata kunci: media pembelajaran; aplikasi kas kecil; kemandirian dan hasil belajar

\section{Pendahuluan}

Adanya pandemic Covid-19 sangat mempengaruhi berbagai aspek kehidupan, tak terkecuali pada aspek pendidikan. Kebijakan mengenai pendidikan di masa Covid-19 tertulis dalam Surat Edaran Nomor 4 Tahun 2020 yang mana di dalamnya dijelaskan bahwa proses belajar mengajar dilaksanakan di rumah melalui pembelajaran jarak jauh. Hal tersebut menuntut guru untuk dapat melakukan adaptasi dalam sistem mengajar, yang biasanya mengajar secara face to face, kini pembelajaran dilakukan dengan menggunakan media daring (Lindawati \& Catur, 2020). Penggunaan media pembelajaran menjadi salah satu faktor yang penting dalam menunjang pembelajaran jarak jauh. Media pembelajaran adalah segala bentuk alat bantu yang dapat digunakan oleh guru dalam menyampaikan materi (Kustandi \& Darmawan, 2020), (Ekayani, 2017).

Pesatnya teknologi saat ini memudahkan guru dalam melakukan variasi untuk mengembangkan media pembelajaran, salah satunya mengembangkan media pembelajaran berbasis web. Selain efektif digunakan untuk menyampaikan materi selama pembelajaran jarak jauh, media pembelajaran berbasis web juga membuat siswa lebih antusias dalam pembelajaran karena materi dikemas secara lebih menarik (Peprizal and Syah, 2020), (Coman 
et al., 2020), (Lin et al., 2017). Salah satu keunggulan media pembelajaran berbasis web adalah materi pembelajaran dapat diperkaya dengan berbagai sumber belajar (Januarisman \& Ghufron, 2016). Pemanfaatan media pembelajaran berbasis web diharapkan dapat memudahkan siswa agar dapat mengaksesnya melalui laptop maupun smartphone mereka (Saputra et al., 2018; Fauzi \& Maksum, 2020).

Berdasarkan hasil wawancara dengan guru mata pelajaran otomatisasi tata kelola keuangan kelas XII di SMK Cendika Bangsa Kepanjen, diperoleh informasi bahwa selama diberlakukannya pembelajaran jarak jauh guru memanfaatkan platform seperti google classroom dan LMS yang dikembangkan oleh SMK Cendika Bangsa. Dengan kegiatan pembelajaran yang full daring, tentunya juga membuat guru kesulitan dalam menjelaskan materi, terutama materi mengenai kas kecil yang mana pada materi tersebut banyak terdapat praktiknya. Hal tersebut membuat siswa kurang dapat memahami materi kas kecil dengan baik.Hal ini menyebabkan rata-rata nilai siswa pada semester lalu lebih rendah jika dibandingkan dengan rata-rata nilai mata pelajaran produktif lainnya. Dari permasalahan tersebut peneliti berinovasi untuk mengembangkan media pembelajaran berbasis website yang bernama EPCA (Educative Petty Cash Application) yang mana di dalamnya terdapat menu simulasi kas kecil, soal latihan, video pembelajaran, dan materi pembelajaran. Siswa dapat mengaksesnya menggunakan smartphone maupun laptop.

Beberapa penelitian sebelumnya yang mengembangkan media pembelajaran berbasis web (Churiyah \& Sakdiyyah, 2020; Divayana et al., 2016; Niemi et al., 2003; Priyambodo et al., 2012; Rohdiani \&Rakhmawati, 2017; Sadikin and Hamidah, 2020; Setyadu \& Qahar, 2017; Tambunan, 2013). Dari penelitian-penelitian tersebut dapat disimpulkan bahwa pengembangan media pembelajaran berbasis web dapat menjadi salah satu alternatif media pembelajaran yang mudah diakses dan dapat meningkatkan kemandirian dan hasil belajar siswa.

\section{Metode}

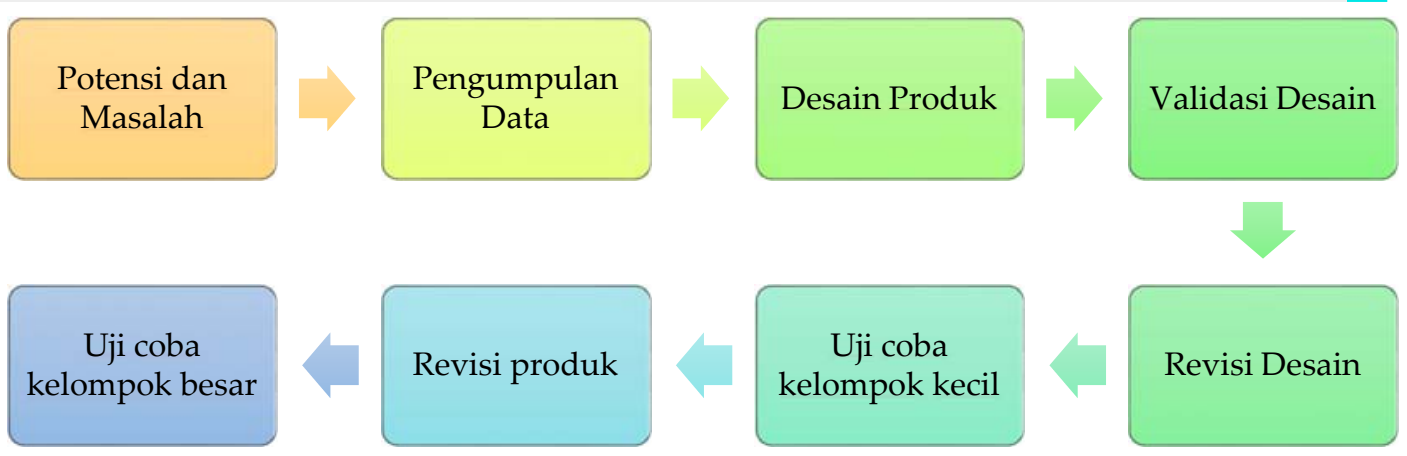

Gambar 1. Tahapan Penelitian

Penelitian ini menggunakan model Research \& Development Sugiyono yang telah dimodifikasi menjadi delapan Tahap untuk mempersingkat waktu (Maulidina et al., 2018). Selain itu, peneliti juga merasa bahwa tujuan penelitian yaitu untuk menghasilkan produk, mengetahui kelayakan produk, dan mengetahui perbedaan hasil belajar siswa yang menggunakan dengan yang tidak menggunakan produk yang dikembangkan, sudah dapat tercapai di tahap kedelapan. 
Tahap pertama, peneliti mengumpulkan informasi terkait permasalahan yang terjadi selama diterapkannya pembelajaran jarak jauh melalui wawancara pendahuluan dengan Guru mata pelajaran. Tahap kedua peneliti mengumpulkan informasi-informasi terkait berupa RPP, silabus, buku, dan materi-materi yang membahas mengenai kas kecil. Tahap ketiga, peneliti membuat rancangan desain produk. Tahap ke empat, media yang dikembangkan peneliti diujicobakan kepada satu orang validator ahli materi dan satu orang validator ahli media. Tahap kelima, produk yang dikembangkan kemudian direvisi sesuai dengan kritik dan saran dari validator ahli materi \& ahli media. Tahap keenam, produk yang telah direvisi kemudian diujicobakan kepada 6 siswa kelas XII OTKP. Tahap ketujuh, produk direvisi kembali sesuai saran-saran dari subjek uji coba kelompok kecil. Tahap kedelapan, produk kemudian diujicobakan kepada seluruh siswa kelas XII OTKP. Dikarenakan hanya terdapat satu kelas untuk XII OTKP, maka peneliti membaginya menjadi 2 kelas, yaitu absen 1-16 menjadi kelas kontrol dan absen 17-32 menjadi kelas eksperimen.

Terdapat dua jenis data yang dihasilkan dalam penelitian ini, yaitu data kualitatif dan data kuantitatif, dimana data kualitatif didapatkan melalui hasil wawancara pendahuluan, kritik dan saran dari ahli materi, ahli media, dan subjek uji coba kelompok kecil. Sedangkan data kuantitatif berupa skor validasi ahli materi, skor validasi media, skor uji coba kelompok kecil, dan skor kemandirian belajar dianalisis menggunakan metode deskriptif presentase. Sedangkan data hasil belajar kognitif dan psikomotorik siswa dianalisis menggunakan uji independent sample t-test untuk menunjukkan perbedaan hasil belajar siswa kelas eksperimen dan kelas kontrol.

\section{Hasil dan Pembahasan}

Produk yang dihasilkan dalam penelitian dan pengembangan ini adalah media pembelajaran kas kecil yang bernama EPCA (Educative Petty Cash Application) berbasis website untuk mata pelajaran otomatisasi tata kelola keuangan. EPCA berbasis web terdiri dari beberapa menu seperti pada Gambar 2 berikut.

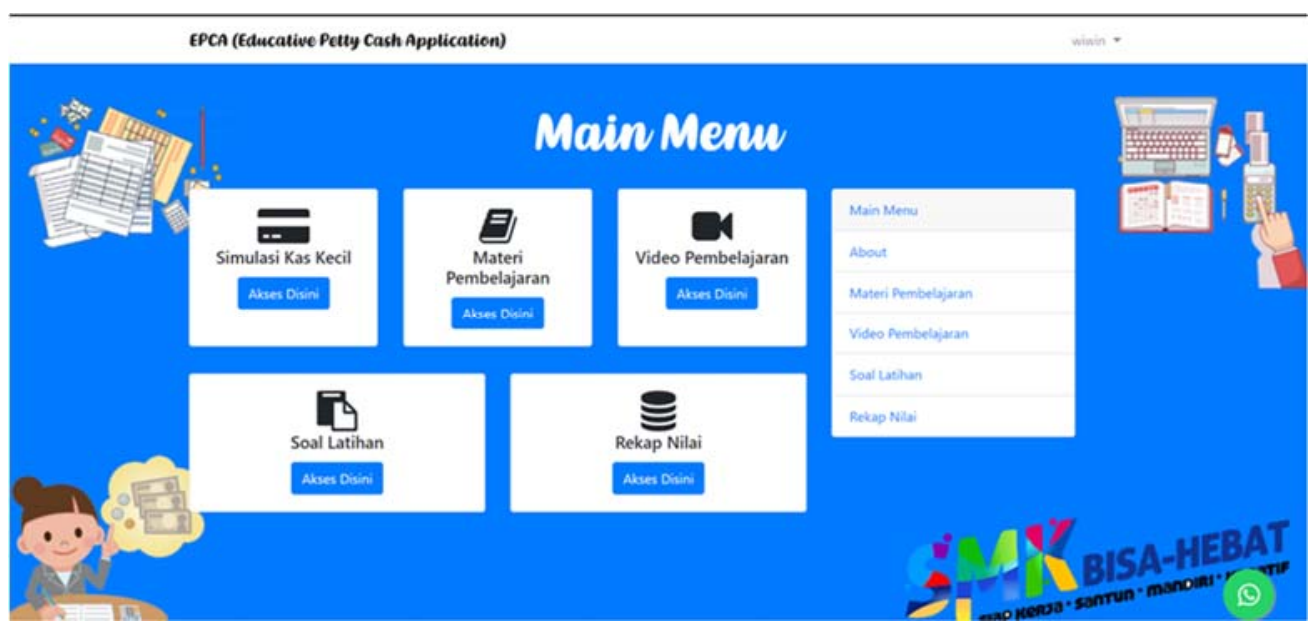

Gambar 2. Menu Utama dalam aplikasi EPCA versi siswa 


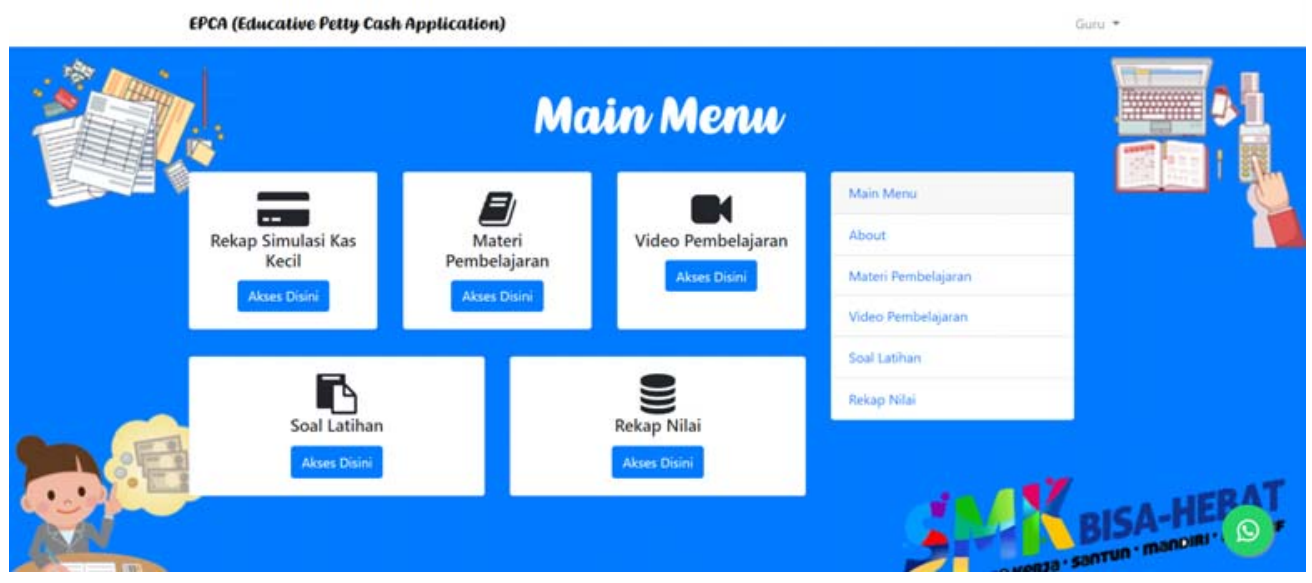

Gambar 3. Menu Utama dalam aplikasi EPCA versi guru

Hasil validasi aplikasi EPCA oleh ahli materi, ahli media, dan subjek uji coba kelompok kecil secara keseluruhan disajikan dalam Tabel 1 berikut:

Tabel 1. Data Hasil Validasi

\begin{tabular}{llll}
\hline No & Validasi & Persentase & Kriteria Validitas \\
\hline 1 & Ahli Materi & $94,67 \%$ & Sangat Valid \\
\hline 2 & Ahli Media & $94,12 \%$ & Sangat Valid \\
\hline 3 & Subjek Uji Coba Kelompok Kecil & $92,67 \%$ & Sangat Valid \\
\hline & Rata-rata & $93,82 \%$ & Sangat Valid \\
\hline
\end{tabular}

Table used by permission (CQomarina, Yashinta Ula, 2021. Data hasil validasi keseluruhan.

Berdasarkan Tabel 1, diketahui rata-rata persentase validasi secara keseluruhan adalah sebesar 93,82\% yang mana dapat disimpulkan bahwa aplikasi EPCA sebagai media pembelajaran kas kecil dinyatakan "Sangat Valid" dan layak digunakan dalam pembelajaran mata pelajaran Otomatisasi Tata Kelola Keuangan di SMK Cendika Bangsa Kepanjen. Hal ini sejalan dengan penelitian sebelumnya, dimana hasil dari validasi ahli materi, ahli media, dan subjek uji coba kelompok kecil dijadikan dasar penentuan layak tidaknya penggunaan media yang dikembangkan dalam pembelajaran (Churiyah \& Sakdiyyah, 2020; Sohibun and Ade, 2017; Munawaroh, 2012)

Keefektifan dan kelayakan EPCA sebagai media pembelajaran didasari oleh ketepatan konsep materi dan kemenarikan tampilan aplikasi EPCA (Kurniawan \& Rohmani, 2019). Di dalam aplikasi EPCA terdapat menu simulasi kas kecil yang mana di dalamnya siswa dapat melakukan praktik pencatatan kas kecil secara digital. Selain itu juga terdapat menu soal latihan yang dapat digunakan siswa untuk mengasah kemampuan kognitifnya. Terdapat pula sajian materi-materi dan video pembahasan kas kecil yang cukup lengkap sehingga dapat membantu siswa dalam meningkatkan kemandirian belajar dan hasil belajar kognitif dan psikomotoriknya.

Selanjutnya, untuk mengukur kemandirian siswa, data dianalisis dengan rumusan dari Arikunto (Prasetiyo and Perwiraningtyas, 2017). Hasil skor kemandirian belajar siswa kelas eksperimen dan kelas kontrol disajikan dalam Tabel 2 berikut. 
Tabel 2. Perbandingan Skor Kemandirian Belajar

\begin{tabular}{|c|c|c|c|c|c|}
\hline \multicolumn{6}{|c|}{ Indikator Kemandirian Belajar Siswa } \\
\hline Kelas & $\begin{array}{l}\text { Percaya } \\
\text { Diri }\end{array}$ & $\begin{array}{l}\text { Kemampuan } \\
\text { Pemecahan } \\
\text { Masalah }\end{array}$ & $\begin{array}{l}\text { Tanggung } \\
\text { Jawab } \\
\text { Belajar }\end{array}$ & $\begin{array}{l}\text { Mandiri dalam } \\
\text { Merencanakan } \\
\text { belajar }\end{array}$ & $\begin{array}{l}\text { Rata- } \\
\text { rata }\end{array}$ \\
\hline $\begin{array}{l}\text { Kelas } \\
\text { Kontrol }\end{array}$ & $74,17 \%$ & 80,62 & 80,93 & 78,75 & $78,62 \%$ \\
\hline $\begin{array}{l}\text { Kelas } \\
\text { Eksperimen }\end{array}$ & $85,83 \%$ & $85,31 \%$ & $84,69 \%$ & $88,12 \%$ & $85,98 \%$ \\
\hline Selisih & $11,66 \%$ & $4,69 \%$ & $3,76 \%$ & $9,37 \%$ & $7,36 \%$ \\
\hline
\end{tabular}

Table used by permission (CQomarina, Yashinta Ula, 2021. Data Kemandirian belajar

Berdasarkan Tabel di atas didapatkan skor perolehan kemandirian belajar pada kelas eksperimen sebesar $85,98 \%$ dan kelas kontrol sebesar 78,62\%. Indikator dengan selisih tertinggi adalah percaya diri, dimana siswa kelas eksperimen cenderung memiliki tingkat percaya diri yang tinggi dikarenakan dalam menu simulasi kas kecil, data-data transaksi yang terinput ke dalam sistem akan otomatis menjadi jurnal kas kecil, sehingga dapat meminimalisir kesalahan. Hal tersebut diperkuat oleh pendapat dari Churiyah and Sakdiyyah (2020) yang menjelaskan bahwa pencatatan kas kecil yang dibuat secara otomatis akan menghasilkan laporan yang lebih akurat. Sehingga hal tersebut dapat membuat tingkat kepercayaan diri siswa dalam membuat laporan kas kecil meningkat. Kepercayaan diri dapat memberikan motivasi siswa dalam memecahkan masalah, sehingga semakin tinggi tingkat kepercayaan diri, semakin kuat pula semangat untuk menyelesaikan tugasnya (Rafli et al., 2018).

Sedangkan indikator dengan perbedaan terendah adalah tanggung jawab belajar dengan kesadaran diri dengan selisih sebesar 3,46\%. Hal ini menunjukkan bahwa kesadaran diri siswa dalam belajar, baik dengan aplikasi EPCA sebagai media pembelajarannya maupun yang tidak menggunakan relatif sama. Kesadaran diri siswa dalam belajar salah satunya dipengaruhi oleh faktor lingkungannya. Pembelajaran yang dilakukan secara daring ini membuat siswa menjadi kurang antusias dalam belajar dikarenakan tidak ada guru yang mendampingi. Dukungan sosial yang berada di lingkungan sekitar siswa akan mempengaruhi kesadaran diri siswa dalam belajar (Lazarus, 2018).

Kemandirian belajar memiliki sifat yang dinamis artinya tidak lepas dari perubahan. Sudiana et al., (2017) menyatakan terdapat indikator yang dapat bertahan dalam kurun waktu tertentu, ada pula yang dapat berubah sesuai dengan situasi. Hal ini berarti terdapat kemungkinan untuk meningkatkan kemandirian belajar siswa. Karakter kemandirian belajar sangat penting bagi siswa dikarenakan anak yang memiliki karakter mandiri sadar akan kemampuannya (Kartina \& Subani, 2020).

Lebih lanjut, untuk mengukur perbedaan hasil belajar kognitif dan psikomotorik siswa kelas eksperimen dengan kelas kontrol dilakukan dengan uji Independent sample t-test berbantuan SPSS 21. Hasil uji independent sample t-test untuk hasil belajar kognitif disajikan dalam Tabel 3. 
Tabel 3. hasil uji independent sample t-test

\begin{tabular}{|c|c|c|c|c|c|c|c|c|c|c|}
\hline \multirow{5}{*}{$\begin{array}{l}\text { Hasil } \\
\text { Belaj } \\
\text { ar } \\
\text { kogn } \\
\text { itif }\end{array}$} & \multicolumn{10}{|c|}{$\begin{array}{l}\text { Independent Samples Test } \\
\text { t-test for Equality of Means }\end{array}$} \\
\hline & & $\mathrm{F}$ & $\begin{array}{l}\mathrm{Si} \\
\mathrm{g} .\end{array}$ & $\mathrm{t}$ & $\mathrm{df}$ & $\begin{array}{l}\text { Sig. } \\
(2- \\
\text { tail } \\
\text { ed) }\end{array}$ & $\begin{array}{l}\text { Mean } \\
\text { Differe } \\
\text { nce }\end{array}$ & $\begin{array}{l}\text { Std. } \\
\text { Error } \\
\text { Differe } \\
\text { nce }\end{array}$ & $\begin{array}{l}95 \% \\
\text { Confic } \\
\text { Interv } \\
\text { Differ } \\
\text { Lowe } \\
\text { r }\end{array}$ & $\begin{array}{l}\text { ce } \\
\text { of the } \\
\text { Upper }\end{array}$ \\
\hline & Equal & 1.5 & .2 & 3.2 & 30 & .00 & 16.875 & 5.2116 & 6.23 & 27.51 \\
\hline & $\begin{array}{l}\text { varian } \\
\text { ces } \\
\text { assum } \\
\text { ed }\end{array}$ & 38 & 25 & 38 & & 3 & & 7 & 136 & 864 \\
\hline & $\begin{array}{l}\text { Equal } \\
\text { varian } \\
\text { ces } \\
\text { not } \\
\text { assum } \\
\text { ed }\end{array}$ & & & $\begin{array}{l}3.2 \\
38\end{array}$ & $\begin{array}{l}26.8 \\
54\end{array}$ & $\begin{array}{l}.00 \\
3\end{array}$ & 16.875 & $\begin{array}{l}5.2116 \\
7\end{array}$ & $\begin{array}{l}6.17 \\
882\end{array}$ & $\begin{array}{l}27.57 \\
118\end{array}$ \\
\hline
\end{tabular}

Table used by permission (CQomarina, Yashinta Ula, 2021. Datahasl Uji Independent sample t-test.

Berdasarkan Tabel di atas diketahui diketahui pada bagian Equal variances assumed nilai Sig. (2-tailed) sebesar 0,003 < 0,05, sehingga dapat ditarik kesimpulan bahwa terdapat perbedaan yang signifikan (nyata) antara hasil belajar kognitif siswa kelas eksperimen dengan hasil belajar siswa kelas kontrol (Nuryadi et al., 2017). Perbedaan hasil belajar yang signifikan ini membuktikan bahwa penggunaan media pembelajaran yang peneliti kembangkan efektif dapat meningkatkan hasil belajar kognitif siswa (Sari, 2021; Juwita et al., 2019; Sulasteri et al., 2018; Rahmawati and Rukiyati, 2018)

Tabel 4. Rata-Rata Hasil Belajar Kognitif

\begin{tabular}{llccll}
\hline \multicolumn{5}{c}{ Group Statistics } \\
\hline & Kelas & $\mathrm{N}$ & Mean & $\begin{array}{l}\text { Std. } \\
\text { Deviation }\end{array}$ & $\begin{array}{l}\text { Std. Error } \\
\text { Mean }\end{array}$ \\
\hline $\begin{array}{l}\text { Hasil Belajar } \\
\text { Kognitif }\end{array}$ & Kelas & 16 & 83.1250 & 11.95478 & 2.98869 \\
& $\begin{array}{l}\text { Eksperimen } \\
\text { Kelas Kontrol }\end{array}$ & 16 & 66.2500 & 17.07825 & 4.26956 \\
\hline
\end{tabular}

Table used by permission (CQomarina, Yashinta Ula, 2021. Rata-rata Hasil Belajar Kognitif.

Tabel 3 menunjukkan bahwa rata-rata hasil belajar kognitif pada kelas eksperimen lebih tinggi dibandingkan dengan kelas kontrol, yaitu 83,12 pada kelas eksperimen dan 66,25 pada kelas kontrol. Hal ini disebabkan oleh kurangnya minat siswa dalam mengerjakan soal posttest, sehingga membuat siswa kurang bersungguh-sungguh dalam mengerjakannya. Salah satu faktor eksternal dalam lingkungan sekolah yang menyebabkan rendahnya minat siswa dalam belajar adalah faktor media pembelajaran yang kurang menarik (Harisnawati et al., 2019; Martiin et al., 2019). Selanjutnya, juga dilakukan uji independent sample t-test untuk 
mengetahui perbedaan signifikan hasil belajar psikomotorik pada kelas eksperimen dan kelas kontrol. Berikut hasil dari uji independent sample t-test pada hasil belajar psikomotorik

Tabel 5. hasil uji independent sample t-test

\begin{tabular}{|c|c|c|c|c|c|c|c|c|c|c|}
\hline \multicolumn{11}{|c|}{ Independent Samples Test } \\
\hline & & \multicolumn{2}{|c|}{$\begin{array}{l}\text { Levene's Test for } \\
\text { Equality of } \\
\text { Variances }\end{array}$} & \multicolumn{7}{|c|}{ t-test for Equality of Means } \\
\hline & & \multirow[t]{2}{*}{$\mathrm{F}$} & \multirow[t]{2}{*}{ Sig. } & \multirow[t]{2}{*}{$\mathrm{t}$} & \multirow[t]{2}{*}{$\mathrm{df}$} & \multirow[t]{2}{*}{$\begin{array}{l}\text { Sig. } \\
(2- \\
\text { taile } \\
\text { d) }\end{array}$} & \multirow[t]{2}{*}{$\begin{array}{l}\text { Mean } \\
\text { Differen } \\
\text { ce }\end{array}$} & \multirow{2}{*}{$\begin{array}{l}\text { Std. } \\
\text { Erro } \\
\mathrm{r} \\
\text { Diffe } \\
\text { renc } \\
\text { e }\end{array}$} & \multicolumn{2}{|c|}{$\begin{array}{l}95 \% \\
\text { Confidence } \\
\text { Interval of the } \\
\text { Difference }\end{array}$} \\
\hline & & & & & & & & & Lower & Upper \\
\hline \multirow[t]{2}{*}{$\begin{array}{l}\text { Hasil } \\
\text { Belajar } \\
\text { Psikom } \\
\text { otorik }\end{array}$} & $\begin{array}{l}\text { Equal } \\
\text { varianc } \\
\text { es } \\
\text { assume } \\
\text { d } \\
\end{array}$ & $\begin{array}{l}3.2 \\
91\end{array}$ & .080 & $\begin{array}{l}2.5 \\
67\end{array}$ & 30 & .015 & 5.56188 & $\begin{array}{l}2.16 \\
659\end{array}$ & $\begin{array}{l}1.137 \\
11\end{array}$ & $\begin{array}{l}9.9866 \\
4\end{array}$ \\
\hline & $\begin{array}{l}\text { Equal } \\
\text { varianc } \\
\text { es not } \\
\text { assume } \\
\text { d }\end{array}$ & & & $\begin{array}{l}2.5 \\
67\end{array}$ & $\begin{array}{l}25.9 \\
62\end{array}$ & .016 & 5.56188 & $\begin{array}{l}2.16 \\
659\end{array}$ & $\begin{array}{l}1.108 \\
07\end{array}$ & $\begin{array}{l}10.015 \\
68\end{array}$ \\
\hline
\end{tabular}

Table used by permission (CQomarina, Yashinta Ula, 2021. Datahasl Uji Independent sample t-test.

Berdasarkan Tabel di atas diketahui diketahui pada bagian Equal variances assumed nilai Sig. (2-tailed) sebesar 0,015 $<0,05$ pada kelas eksperimen, dan 0,016 $<0,05$ pada kelas kontrol. Sehingga dapat ditarik kesimpulan bahwa terdapat perbedaan yang signifikan (nyata) antara hasil belajar psikomotorik siswa kelas eksperimen dengan hasil belajar siswa kelas kontrol (Nuryadi et al., 2017). Perbedaan hasil belajar yang signifikan ini membuktikan bahwa penggunaan media pembelajaran yang peneliti kembangkan efektif dapat meningkatkan hasil belajar psikomotorik siswa (Astuti et al., 2018; Korkmaz, 2012; Muslim et al., 2018)

Tabel 6. Rata-Rata Hasil Belajar Psikomotorik

\begin{tabular}{llccll}
\hline Group Statistics & Kelas & N & Mean & $\begin{array}{l}\text { Std. } \\
\text { Deviation }\end{array}$ & $\begin{array}{l}\text { Std. Error } \\
\text { Mean }\end{array}$ \\
\hline $\begin{array}{l}\text { Hasil Belajar } \\
\text { Psikomotorik }\end{array}$ & $\begin{array}{l}\text { Kelas } \\
\text { Eksperimen }\end{array}$ & 16 & 90.5206 & 4.76902 & 1.19226 \\
\cline { 2 - 5 } & Kelas Kontrol & 16 & 84.9588 & 7.23618 & 1.80904 \\
\hline
\end{tabular}

Table used by permission (CQomarina, Yashinta Ula, 2021. Data hasil rata-rata hasil belajar psikom otorik.

Tabel 5 menunjukkan bahwa rata-rata hasil belajar psikomotorik pada kelas eksperimen lebih tinggi dibandingkan dengan kelas kontrol, yaitu 90,52 pada kelas eksperimen dan 84,95 pada kelas kontrol. Perbedaan hasil belajar psikomotorik tersebut dikarenakan ketika diajar menggunakan aplikasi EPCA siswa lebih tertarik dan termotivasi untuk belajar karena dengan aplikasi EPCA pembelajaran kas kecil lebih praktis. Hal ini sejalan dengan penelitian dari Puspitarini and Hanif (2019); (Amirkhanova et al., 2016; Hung et al., 2011) yang mengemukakan bahwa salah satu upaya untuk meningkatkan motivasi peserta didik adalah dengan menggunakan media pembelajaran yang menarik. Berdasarkan hal tersebut maka dapat disimpulkan bahwa penggunaan aplikasi EPCA (Educatuve Petty Cash Application) sebagai media pembelajaran kas kecil dapat meningkatkan hasil belajar psikomotorik siswa. 
Hal ini sejalan dengan penelitian (Maria et al., n.d.; Okedeyi et al., 2015) yang menjelaskan bahwa pembelajaran yang menerapkan multimedia dalam proses pembelajarannya akan memudahkan siswa dalam memahami materi yang diajarkan.

\section{Simpulan}

Penelitian dan pengembangan ini menghasilkan aplikasi EPCA berbasis website sebagai media pembelajaran kas kecil pada mata pelajaran otomatisasi tata kelola keuangan kelas XII di SMK Cendika Bangsa Kepanjen. Aplikasi EPCA dapat diakses melalui laman epca.argia.co.id di google chrome maupun aplikasi browser lainnya.

Media pembelajaran pada penelitian ini telah dinyatakan 'Sangat Valid' dan layak digunakan sebagai media pembelajaran kas kecil pada mata pelajaran otomatisasi tata kelola keuangan melalui validasi oleh ahli materi, ahli media, dan subjek uji coba kelompok kecil. Selain itu aplikasi EPCA berbasis website juga secara efektif dapat meningkatkan kemandirian siswa. Hal tersebut dibuktikan dengan tingginya tingkat kemandirian belajar siswa kelas eksperimen dibandingkan dengan siswa kelas kontrol. Aplikasi EPCA berbasis website juga telah terbukti dapat meningkatkan hasil belajar kognitif dan psikomotorik siswa berdasarkan hasil uji independent sample t-test. Aplikasi ini juga memungkinkan diakses menggunakan laptop maupun smartphone sehingga memudahkan siswa dalam mengaksesnya.

Aplikasi EPCA berbasis website ini hanya terfokus pada mata pelajaran otomatisasi tata kelola keuangan yang membahas mengenai kas kecil, terutama metode dana tidak tetap, sehingga diharapkan peneliti selanjutnya untuk mengembangkan media pembelajaran pada metode dana tetap.

\section{Ucapan Terima Kasih}

Penulis mengucapkan terimakasih kepada Universitas Negeri Malang dan SMK Cendika Bangsa Kepanjen yang telah memfasilitasi dan memberi izin kepada peneliti untuk melakukan kegiatan penelitian dan pengembangan ini.

\section{Daftar Rujukan}

Amirkhanova, K.M., Ageeva, A.V., Fakhretdinov, R.M., (2016). Enhancing Students' Learning Motivation through Reflective Journal Writing. Presented at the 2nd International Forum on Teacher Education, The European Proceedings of Social and Behavioural Sciences Ep-SBS pp. 14-18. https://doi.org/10.15405/epsbs.2016.07.3

Astuti, I.A.D., Putra, I.Y., Bhakti, Y.B., (2018). Developing Practicum Module of Particle Dynamics Based on Scientific Methods to Improve Students' Science Process Skills. Scientiae Educatia: Jurnal Pendidikan Sains 7, 183-196. https://doi.org/10.24235/sc.educatia.v7i2.2513

Churiyah, M., Sakdiyyah, D.A., (2020). P-Cash App Based on Microsoft Office Access to Improve Learning Outcomes of Vocational High School Students. Sys Rev Pharm 11, 499-506. http://dx.doi.org/10.31838/srp.2020.7.73

Coman, C., Țîru, L.G., Meseșan-Schmitz, L., Stanciu, C., Bularca, M.C., (2020.) Online Teaching and Learning in Higher Education during the Coronavirus Pandemic: Students' Perspective. Sustainability 12, 10367. https://doi.org/10.3390/su122410367

Divayana, D.G.H., Suyasa, P.W.A., Sugihartini, N., (2016). Pengembangan Media Pembelajaran Berbasis Web Untuk Matakuliah Kurikulum dan Pengajaran di Jurusan Pendidikan Teknik Informatika Universitas Pendidikan Ganesha. Jurnal Nasional Pendidikan Teknik. Informatika 5, 149. https://doi.org/10.23887/janapati.v5i3.9922

Ekayani, N. luh P., (2017). Pentingnya Penggunaan Media Pembelajaran Untuk Meningkatkan Prestasi Belajar Siswa. Ganesha University of Education. 
Fauzi, Maksum, H., 2020. The Development of Web Based Learning Media Network and Computer Basic at SMK Negeri 1 Lembah Melintang. Jurnal Pendidikan Teknologi Informasi 4, 129-137.

Febri Rafli, M., Syahputra, E., Yusnadi, Y., (2018). Influence of Problem Based Learning Model and Early Mathematics Ability to Mathematical Communication Skills and Self-Confidence in Junior High School. EDUCATION 6, American Journal of Educational Research 1539-1545. https://doi.org/10.12691/education-6-11-12

Harisnawati, H., Rahayu, S., \& Sumarni, R. (2020). Analysis of Factor Causing The Low Interest of Student Continuing Education at SMAN 1 IV Koto Aur Malintang West Sumatra. Jurnal Ilmu Sosial Mamangan, $8(1), 8-12$.

Hung, C. M., Hwang, G. J., \& Huang, I. (2012). A project-based digital storytelling approach for improving students' learning motivation, problem-solving competence and learning achievement. Journal of Educational Technology \& Society, 15(4), 368-379.

Januarisman, E., \& Ghufron, A. (2016). Pengembangan media pembelajaran berbasis web mata pelajaran ilmu pengetahuan alam untuk siswa kelas VII. Jurnal Inovasi Teknologi Pendidikan, 3(2), 166-182.

J Juwita, M. D., Hakiki, M., Gerieska, O., Lubis, S. F., Rizal, F., \& Giatman, M. (2019, December). The effect of the web-based learning media on learning outcomes. In International Conference on Education, Science and Technology (pp. 31-35). Redwhite Press. https://doi.org/: https://doi.org/10.32698//tech1315121

Kartina, L., \& Subani, S. (2020). Analisis Kemandirian Siswa MTs Pada Mata Pelajaran IPA. Schrödinger: Journal of Physics Education, 1(1), 30-35.

Korkmaz, Ö. (2012). The effects of web-based learning on the psychomotor skills and attitude toward course of students. Energy Education Science and Technology Part B: Social and Educational Studies, 4(3), 12791288.

Kurniawan, M. F. T., \& Rokhmani, L. (2019). PENGEMBANGAN MEDIA PEMBELAJARAN INTERAKTIF BERBASIS APLIKASI ANDROID UNTUK MENINGKATKAN HASIL BELAJAR KEWIRAUSAHAAN (Studi Pada Kelas XI APK SMK Muhammadiyah 3 Singosari Materi Aspek Organisasi). Jurnal Pendidikan Ekonomi, 12(1), 7277.

Kustandi, C., \& Darmawan, D. (2020). Pengembangan Media Pembelajaran: Konsep \& Aplikasi Pengembangan Media Pembelajaran bagi Pendidik di Sekolah dan Masyrakat. Prenada Media.

Lazarus, D. (2018). Student Self-Responsibility in The Indonesian Distance Education System. JAS-PT (Jurnal Analisis Sistem Pendidikan Tinggi Indonesia), 1(2), 69-78.

Lin, M. H., \& Chen, H. G. (2017). A study of the effects of digital learning on learning motivation and learning outcome. Eurasia Journal of Mathematics, Science and Technology Education, 13(7), 3553-3564. https://doi.org/10.12973/eurasia.2017.00744a

Lindawati, Y. I., \& Rahman, C. A. (2020, November). Adaptasi Guru Dalam Implementasi Pembelajaran Daring di Era Pandemi Covid-19. In Prosiding Seminar Nasional Pendidikan FKIP (Vol. 3, No. 1, pp. 60-67).

Maria, U., Rusilowati, A., \& Hardyanto, W. (2019). Interactive multimedia development in the learning process of Indonesian culture introduction theme for 5-6 year old children. Journal of Primary Education, 8(3), 344-353. https://doi.org/10.15294/jpe.v8i3.27929

Wicaksono, L., \& Purwanti, P. (2019) ANALISIS TENTANG RENDAHNYA MINAT BELAJAR PESERTA DIDIK KELAS XI SMA NEGERI 5 PONTIANAK. Jurnal Pendidikan dan Pembelajaran Khatulistiwa, 8(7), 425-436.

Maulidina, M. A., Susilaningsih, S., \& Abidin, Z. (2018). Pengembangan Game Based Learning Berbasis Pendekatan Saintifik Pada Siswa Kelas IV Sekolah Dasar. JINOTEP Uurnal Inovasi Dan Teknologi Pembelajaran): Kajian Dan Riset Dalam Teknologi Pembelajaran, 4(2), 113-118.

LAILATUL MUNAWAROH, D. E. W. I. (2017). PENGEMBANGAN PERMAINAN KARTU UNO SEBAGAI MEDIA PEMBELAJARAN MATA PELAJARAN ADMINISTRASI KEUANGAN KELAS XI APK 1 DI SMKN 2 BUDURAN SIDOARJO. Jurnal Pendidikan Administrasi Perkantoran (JPAP), 5(1).

Muslim, S., Gitama, N. P., Suprianto, B., Rahmadyanti, E., \& Kusumawati, N. (2018). Influence of learning media based on adobe flash professional to psychomotor domain learning outcomes on plc courses viewed from level of creative thinking student. Jurnal Pendidikan Vokasi, 8(3), 267-276. http://dx.doi.org/10.21831/jpv.v8i3.21552

Niemi, H., Nevgi, A., \& Virtanen, P. I. (2003). Towards self-regulation in web-based learning. Journal of Educational Media, 28(1), 49-71. https://doi.org/10.1080/1358165032000156437 
Nuryadi, N., Astuti, T. D., Sri Utami, E., \& Budiantara, M. (2017). Dasar-Dasar Statstk Penelitan.

Okedeyi, A. S., Oginni, A. M., Adegorite, S. O., \& Saibu, S. O. (2015). The Relevance of Multi Media Skills in Teaching and Learning of Scientific Concepts in Secondary Schools in Lagos State, Nigeria. Journal of Education and Practice, 6(15), 150-154.

Peprizal, P., \& Syah, N. (2020). Pengembangan Media Pembelajaran Berbasis Web pada Mata Pelajaran Instalasi Penerangan Listrik. Jurnal Imiah Pendidikan dan Pembelajaran, 4(3), 455-467.

Prasetiyo, N. A., \& Perwiraningtyas, P. (2017). Pengembangan Buku Ajar Berbasis Lingkungan Hidup Pada Mata Kuliah Biologi di Universitas Tribhuwana Tunggadewi. Jurnal Pendidikan Biologi Indonesia, 3(1), 19-27.

Priyambodo, E., Wiyarsi, A., \& Permanasari, L. (2012). Pengaruh media pembelajaran interaktif berbasis web terhadap motivasi belajar mahasiswa. Jurnal Kependidikan: Penelitian Inovasi Pembelajaran, 42(2).

Puspitarini, Y. D., \& Hanif, M. (2019). Using Learning Media to Increase Learning Motivation in Elementary School. Anatolian Journal of Education, 4(2), 53-60.

Rahmawati, D. I., \& Rukiyati, R. (2018, November). Developing Pop-Up Book Learning Media to Improve Cognitive Ability of Children Aged 4-5 Years. In 4th International Conference on Early Childhood Education. Semarang Early Childhood Research and Education Talks (SECRET 2018). Atlantis Press. https://doi.org/10.2991/secret-18.2018.10

Rohdiani, F. (2017). Pengembangan Media Pembelajaran Berbasis Web pada Mata Pelajaran Dasar Elektronika di SMK Negeri 3 Jombang. Jurnal Pendidikan Teknik Elektro, 6(1).

Sadikin, A., \& Hamidah, A. (2020). Pembelajaran Daring di Tengah Wabah Covid-19:(Online Learning in the Middle of the Covid-19 Pandemic). Biodik, 6(2), 214-224.

Saputra, H. D., Nasrun, N., \& Wakhinuddin, W. (2018). Development of Web-Based Learning Media in Vocational Secondary School. VOLT: jurnal ilmiah Pendidikan teknik elektro, 3(1), 37-41. https://doi.org/10.30870/volt.v3i1.2975

Sari, D. N. (2021). Implementation of Educative Learning Media Counting Tree to Improve Student's Cognitive Abilities in Kartika Tanjung Morawa Kindergarten. Britain International of Linguistics Arts and Education (BIoLAE) Journal, 3(1), 22-28. https://doi.org/10.33258/biolae.v3i1.406

Setyadi, D., \& Qohar, A. B. D. (2017). Pengembangan Media pembelajaran matematika berbasis web pada materi barisan dan deret. Kreano, Jurnal Matematika Kreatif-Inovatif, 8(1), 1-7. http://dx.doi.org/10.15294/kreano.v8i2.5964

Sohibun, S., \& Ade, F. Y. (2017). Pengembangan media pembelajaran berbasis virtual class berbantuan Google Drive. Tadris: Jurnal Keguruan dan Ilmu Tarbiyah, 2(2), 121-129. https://doi.org/10.24042/tadris.v2i2.2177

Sudiana, R., Fatah, A., \& Khaerunnisa, E. (2017). Kemandirian belajar mahasiswa melalui pembelajaran berbasis virtual class. JPPM (Jurnal Penelitian dan Pembelajaran Matematika), 10(1).

Sulasteri, S., Rasyid, M. R., \& Akhyar, M. (2018). The Effect of the use of Learning Media Based On Presentation Media On Interest and Mathematical Learning Outcomes. MaPan: Jurnal Matematika dan Pembelajaran, 6(2), 221-236. https://doi.org/10.24252/mapan.2018v6n2a8

Tambunan, H. (2013). Pengembangan pembelajaran berbasis website dalam matakuliah pengaturan mesin listrik. Jurnal Cakrawala Pendidikan, 5(1). https://doi.org/10.21831/cp.v5i1.1260 